\title{
Role of Microbes in Dairy Industry
}

\author{
Anil Kumar* and Nikita Chordia \\ School of Biotechnology, Devi Ahilya University, India
}

Submission: March 3, 2017; Published: September 22, 2017

*Corresponding author: Anil Kumar, School of Biotechnology, Devi Ahilya University, Khandwa Rd., Indore-452001,India,

Email: ak_sbt@yahoo.com

\section{Abstract}

Milk represents a good source of nutrients and liquid for hydration and is known to humanity thousands of years ago. The fermentation of milk provides a simple way to increase its shelf-life while improving its safety. Different strains of bacteria and fungi are used for fermentation of milk in order to produce a wide variety of dairy products viz. curd, yogurt, cheese, kefir and kumis. The main bacteria are lactic acid bacteria that are used for coagulation of milk and thereafter, these can be processed for diverse products.

\section{Introduction}

Since ancient times, dairy products have been part of human diet. These serve as good source of calcium, vitamin D, proteins and other essential nutrients. These products also provide phosphorus, potassium, magnesium, and various vitamins viz. vitamin A (retinols), vitamin B12 (cyanocobalamin), and riboflavin. Various fermented dairy products are prepared using different microbial strains. Microbes ferment the carbohydrates present in milk, which is mainly lactose to lactic acid and some other products. The acid precipitates the proteins in the milk; therefore fermented products are usually of thicker consistency than milk. The high acidity and low $\mathrm{pH}$ hinders the growth of other bacteria including pathogens. The fermentation of milk provided a simple way to increase its shelf-life while improving its safety. Humans learned to control fermentation processes from the initial accidental events in fermentation. This learning of controlled fermentation of milk in domestic practices gave rise to a diverse dairy products influenced by habits of different ethnicities, geographical environments and type of dairy farming [1]

Now, a huge variety of fermented dairy products are available for consumers. Although a small proportion of these products are homemade, most of them are produced industrially. The production of fermented products is economically important in many countries. As the requirement of fermented products is increasing day by day, and in many countries dairy industries are contributing in economic growth. The first example of fermented milk was presumably produced accidentally by nomads. This milk turned sour and coagulated under the influence of certain microorganisms. By luck it was having harmless, acidifying type and non toxinproducing bacteria.

Various types of fermented milks and derived products have been developed in all parts of the world each with its own characteristic history. Their nature depends very much on the type of milk used, on the pre-treatment of the milk, on the temperature (climate), conditions of fermentation and on the subsequent technological treatments. Most commonly used dairy products include curd, yogurt, cheese, kefir and kumis [2].

\section{Curd}

Curd is made by curdling or coagulating the milk. This can be done by mixing edible acidic substances in to the milk, such as lemon juice or vinegar. By adding these substances to the milk, it will curdle the milk and separate into two parts. The liquid part is the whey and the solid milk is the curd. The whey contains whey proteins of the milk, whereas the curds are the milk proteins or casein. Sometimes old milk might get soured and is separated without any added acidic substance. This happens because raw milk contains Lactobacillus. Lactobacillus is a genus of bacteria that converts sugars into lactic acid by means of fermentation. Milk contains a sugar called as lactose, a disaccharide (compound sugar) having $\beta-1$, 4- glycosidic bond between galactose and glucose. Lactobacillus converts lactose of the milk into lactic acid which imparts the sour taste to curd [3]. 


\section{Yogurt}

Yogurt is most commonly used dairy product. It is prepared by heating the milk up to nearly $80^{\circ} \mathrm{C}$ in order to kill any additional bacteria that may be present and to denature milk proteins. The milk is then allowed to cool slowly to around $45^{\circ} \mathrm{C}$, and thereafter, it is inoculated with a bacteria, and is allowed to ferment at room temperature. The bacteria used are Lactobacillus delbrueckii subsp. bulgaricus and Streptococcus salivarius subsp. thermophilus. If bacteria is not available, then a spoonful of yogurt can also be used as it contains bacteria. Probiotic bacteria like Streptococcus thermophilus, Lactobacillus acidophilus and bifidobacteria can also be used for the production of yogurt and it is commonly referred as bioyogurt. Many evidences indicated that consumption of 'probiotic' microorganisms helps in maintaining a favorable microbial profile and is resulted in several therapeutic benefits [4].

In industry, large quantity of yogurt is produced that is affected by number of factors viz. choice of milk, milk standardization, milk additives, de-aeration, homogenization and heat-treatment, choice of culture and plant design. The milk used for yogurt production must be of the highest bacteriological quality. It must have a low content of bacteria and substances which may impede the development of the yogurt culture. It must not contain antibiotics, bacteriophages or sterilizing agents. The fat and dry solids contents of the milk must be standardized and additives like sweetener or sugar and stabilizer can be used. The air content of the milk should be as low as possible so that viscosity and stability of the yogurt is improved. To assure uniform distribution of milk fat and to prevent creaming during incubation period, milk is homogenized. The milk is heated before inoculation to improve its properties as a substrate for the bacterial culture. Many types of yogurt cultures are available that can be selected based on the type of yogurt production. The plant layout is very important as the selection and dimensions of pipes, valves, pumps, coolers etc affects the production [5].

\section{Cheese}

Cheese is a fermented milk product and historically serving as a mean of preserving milk. Cheese making occurs in three main stages: In the first stage, milk is moulded into solid curd and liquid whey by the coagulation of the milk protein, casein. The coagulation of casein is done through two complementary methods: acidification and proteolysis. Acidification occurs when lactic acid bacteria ferment the disaccharide lactose to produce lactic acid. Originally, it can be done by naturally occurring lactic acid bacteria in the milk but today, dairy industries usually standardize the process by the addition of domesticated bacterial cultures, including strains of Lactococcus lactis, Streptococcus thermophilus and Lactobacillus sp. The production of acid by these bacteria causes casein to coagulate slowly. This process is often assisted by the addition of the enzyme, chymosin (active ingredient in rennet). Chymosin removes negatively charged portion of casein that results in rapid aggregation of casein proteins.

In the second stage, curd is separated containing the casein and milk fat from the whey. Depending on the type of cheese, the curd can be heated, salted, pressed and is moulded into various shapes and sizes. Cheese can be eaten afresh at this point, or can be left to age in a damp, cool place. During the aging stage, cheese is truly transformed from fresh cheese into the myriad flavours, aromas, and textures of mature cheese. As a normal part of the aging process, cultures and lactic acid bacteria continue to grow and metabolize the interior of the cheese, while the surface of a cheese is colonized by bacteria and fungi that form a multispecies bio-film called as 'rind' of the cheese [6].

Diversity in the cheese flavor, smell and texture is because of different microbes. Cheese flavor is associated with the amino acid catabolism. The ability of lactic acid bacteria and other cheese microorganisms to degrade amino acids to aroma compounds is highly strain dependent. These are equipped with enzyme systems for using amino acids in their metabolism. Different amino acids catabolism gives different flavors' as follows [7,8]:

I. Branched-chain amino acids (Leu, Ile, Val) are converted to malty, fruity and sweaty flavors.

II. Aromatic amino acids (Phe, Tyr, Trp) produce floral, chemical and faecal flavors.

III. Aspartic acid (Asp) is catabolised into buttery flavors.

IV. Sulphur containing amino acids (Met, Cys) are transferred to boiled cabbage, meaty and garlic flavors.

\section{Kefir}

Kefir is a fermented milk beverage which has its ancient origin in Eastern Europe. This light alcoholic beverage is prepared by inoculation of raw milk with irregularly shaped, gelatinous white/yellow grain called kefir grains. These Kefir grains have varying and complex microbial composition that includes species of yeasts, lactic acid bacteria, acetic acid bacteria and mycelial fungi. Lactic acid bacteria included in kefir are Lactobacillus fermentum, Lactobacillus acidophilus, Lactobacillus helveticus, Lactobacillus casei, Lactobacillus kefiri, Leuconostoc mesenteroides, Lactobacillus parakefiri, Lactobacillus brevis and Lactococcus lactis. Acetic acid bacteria include Acetobacter aceti and Acetobacter rasens; yeasts include Candida lambica, Kluyveromyces marxianus, Saccharomyces exiguous and Torula kefir. The population composition may differ based on the origin of grain or the method and substrate by which grains have been cultured. A symbiotic relationship exists between the microbes present in 
the Kefir grains and it has been shown that there are specific species that always occur in the grains $[9,10]$.

\section{Kumis (Koumiss)}

Kumis and kefir are similar dairy products but kumis is produced from a liquid starter culture as compared to solid kefir "grains". It has mild alcohol content as compared to kefir because mare's milk contains more sugars than other milks. It is very popular in Kirgizstan, Mongolia, Kazakhstan and some regions of Russia and Bulgaria. It is usually made from, area's milk by spontaneous fermentation of lactose to lactic acid and alcohol. Depending on the lactic acid contents, kumis is of three types- strong, moderate and light.

A. Strong kumis: It is generated by lactic acid bacteria like Lactobacillus bulgaricus, Lactobacillus rhamnosus. There is acidification of milk to $\mathrm{pH} 3.6-3.3$ and conversion ratio of lactose into lactic acid is about $80-90 \%$.

B. Moderate kumis: It involves Lactobacillus bacteria viz. L. Acidophilus, L. Plantarum, L. Casei, L. fermentum with restricted acidification properties that lower the $\mathrm{pH}$ to $4.5-3.9$ at the end of the process and the conversion ratio averages $50 \%$.

C. Light kumis: It is a slightly acidified product $(\mathrm{pH} 4.5-$ 5.0) and is produced using Streptococcus thermophilus and Streptococcus cremoris [11].

\section{Acknowledgement}

Authors acknowledge the facilities of the Department of Biotechnology, Ministry of Science and Technology, Government of India, New Delhi (DBT) under the Bioinformatics Sub Centre as well as M.Sc. Biotechnology program used in the present work.

\section{References}

1. de los Reyes-Gavilán CG, Fernández M, Hudson JA, Korpela R (2015) Role of microorganisms present in dairy fermented products in health and disease. Biomed Res Int 1-2.

2. Wouters JT, Ayad EH, Hugenholtz J, Smit G (2002) Microbes from raw milk for fermented dairy products. Intl Dairy J 12(2): 91-109.

3. Ledenbach LH, Marshall RT (2009) Microbiological spoilage of dairy products. In: Compendium of the Microbiological spoilage of foods and beverages. Springer 41-67.

4. Lourens-Hattingh A, Viljoen BC (2001) Yogurt as probiotic carrier food. Intl Dairy J 11(1): 1-17.

5. Soukoulis C, Panagiotidis P, Koureli R, Tzia C (2007) Industrial yogurt manufacture: Monitoring of fermentation process and improvement of final product quality. J Dairy Sci 90(6): 2641-2654.

6. Button JE, Dutton RJ (2012) Cheese microbes. Curr Biol 22(15): 587589.

7. Yvon M, Rijnen L (2001) Cheese flavour formation by amino acid catabolism. Intl Dairy J 11(4): 185-201.

8. Ardö Y (2006) Flavour formation by amino acid catabolism. Biotechnol Adv 24(2): 238-242.

9. Witthuhn RC, Schoeman T, Britz TJ (2005) Characterisation of the microbial population at different stages of Kefir production and Kefir grain mass cultivation. Intl Dairy J 15(4): 383-389.

10. Pintado ME, Da Silva JA, Fernandes PB, Malcata FX, Hogg TA (1996) Microbiological and rheological studies on Portuguese kefir grains. Int J Food Sci Technol 31(1): 15-26.

11. Danova S, Petrov K, Pavlov P, Petrova P (2005) Isolation and characterization of Lactobacillus strains involved in koumiss fermentation. Intl J Dairy Technol 58(2): 100-105.

\section{Your next submission with Juniper Publishers will reach you the below assets}

- Quality Editorial service

- Swift Peer Review

- Reprints availability

- E-prints Service

- Manuscript Podcast for convenient understanding

- Global attainment for your research

- Manuscript accessibility in different formats

( Pdf, E-pub, Full Text, Audio)

- Unceasing customer service

Track the below URL for one-step submission https://juniperpublishers.com/online-submission.php 